\title{
Russian media speech on RTR Moldova broadcasting
}

\author{
O. V. Tikhonova, A. A. Slobodyanyuk \\ Lomonosov Moscow State University, \\ 1, Leninskie Gory, Moscow, 119991, Russian Federation
}

For citation: Tikhonova, O. V., Slobodyanyuk, A. A. (2021). Russian media speech on RTR Moldova broadcasting. Media Linguistics, 8 (1), 83-89. https://doi.org/10.21638/spbu22.2021.107

The article presents the results of a study of the specifics of Russian media speech in the Republic of Moldova on the example of news broadcasts of the RTR Moldova TV-channel. The actual modern position of the Russian language on the territory of the country within the framework of the current state policy and the situation of Russian-language broadcasting in the country were studied. Theoretical material on the specifics of Russian language in the Republic of Moldova was studied and systematized. The history of the creation and specifics of the functioning of the Russian-language TV-channel RTR Moldova were reviewed in terms of current legislation. Methods of quantitative and comparative analysis, induction, synthesis of theoretical and practical knowledge were used. The study's empirical base includes video material of 41 news programs of "Vesti-Moldova" and "Vesti nedeli-Moldova". Broadcasts in 2019 comprised the overall chronological period of the research, thanks to the use of a "seasonal" sample (a week of winter, spring, summer and autumn seasons), which contributed to a more objective identification of the dynamics of the presenters' and correspondents' media speech on RTR Moldova. The article provides a classification of errors related to grammar, spelling, stylistics of offscreen text and logic of operational information presentation. The features of using means of artistic expression were also studied. Tendencies of bilingualism in the speech of inhabitants of the Republic of Moldova are indicated, which are reflected in the television broadcast, are highlighted in the article. At the same time, it is emphasized that on-air programs in Russian are in demand by the audience, however, at the state level, the process of imposing content in Romanian on the viewer is strongly supported. In this regard, the volume of Russian-language broadcasts is decreasing every year.

Keywords: bilingualism, language interference, media speech, television of Moldova.

Introduction. The former republics of the Soviet Union today still retain Russian as one of the main languages of their inhabitants. In the Republic of Moldova it is considered official on the territory of the unrecognized state - the Pridnestrovian Moldavian Republic (PMR), in the rest of the country the use of the Russian language is only allowed.

The presence of Russian-language TV-channels throughout Moldova is an important component of the country's media economy. This is primarily due to the fact that a considerable percentage of residents speaking Russian. The results of the last complete census of the population of Moldova (2014, excluding the territory of the PMR) showed that $9.7 \%$ of residents consider Russian to be their native language, and $14.5 \%$ - as the everyday language. As for the Romanian language, $80.2 \%$ of the population consider it their native language, and $78.6 \%$ consider it daily. While in Pridnestrovie, which was not

(C) St. Petersburg State University, 2021 
taken into account in the general population census of the Republic of Moldova, Russian is the most common language, and $29.1 \%$ of the population, according to the 2015 PMR census, are Russians by origin and occupy the first place among all nationalities of the unrecognized state.

Since April 2009 in Moldova, against the background of an active anti-Russian campaign, there is a process of quantitative reduction of information and copyright programs produced in Russia on the territory of this state. Nevertheless, the viewers of Republic of Moldova still have the opportunity to watch the Russian international TV-channel RTRPlaneta, which broadcasts the daily socio-political talk show " 60 minut" of the TV channel "Rossiya 1".

Despite the gradual decrease in the air volume of programs in Russian in the layout of the audiovisual media in Moldova, the content continues to be highly demanded by the target audience, as evidenced by the ratings of Russian-language TV-channels in the country. According to the statistics of the research company AGB Nielsen for December 2019, RTR Molodva, which is $50 \%$ owned by the largest media holding in Russian Federation Vserossiiskaia gosudarstvennaia teleradiokompaniia (VGTRK) occupies the first line in the rating. In this regard, the TV-channel causes the greatest scientific interest from the point of view of studying the peculiarities of the Russian media speech in Moldova.

Speaking about the historical roots of the Russian language in this country, the linguist T. P. Mlechko in the article "Why did "tysiachkii" become "nanash", and whose fault is it that I am "finan"?" calls the reasons for the emergence of the Moldavian version of Russian language:

1. centuries-old close ties between the languages of the Slavs, Romanians and Moldovans;

2. "many of today's Russians in Moldova are not first-generation migrants, but children, grandchildren and much more distant descendants of those who once moved to Bessarabia, Moldavia" [Mlechko, 1997: 127];

3. "the natural numerical predominance of population of the titular nationality and Moldovan-Russian bilingualism" [Mlechko, 1997: 127];

4. widespread interethnic marriages in the country;

5. "the language policy in different periods was aimed at the Romanization / Moldovanization of education, culture, science and other social spheres, which strengthened the assimilating influence of this linguacultural dominant on Russians and adherents of the Russian language and culture" [Mlechko, 1997: 127];

6. observance of national traditions by the prevailing rural population of Moldova and maintenance of a linguistic and cultural environment.

The research conducted using such methods as qualitative analysis, comparative analysis, induction, synthesis of theoretical and practical knowledge is devoted to the influence of peculiarities of Russian language in the Republic of Moldova on the media speech in Russian-language television broadcast on the example of RTR Moldova TV-channel. The empirical basis of the research was the materials of the news programs "Vesti-Moldova" and "Vesti nedeli-Moldova" of the mentioned TV channel, the total chronological period was broadcast in 2019: according to the sample, winter weeks - from January 14 to 19 ; springs - from 15 to 20 April; summer - from 15 to 20 July; autumn - from 14 to 18 October. 
Media speech in Russian-language TV-broadcast. Several in the course of the undertaken research, a number of features of the Russian language in Moldova were revealed, which in turn is due not only to the historical Soviet past, but also to the national linguistic culture of the Republic of Moldova.

For example, the TV broadcast shows usage of Romanian words from different spheres of life in the off-screen text of plots and reports in the Russian speech of the hosts on the RTR Moldova: for example, instead of the word "mayor" - "primar", and "city hall" "primărie". The phrase "city of federal significance", habitual in Russia, is replaced by the Moldovan "municipal"; "the head of [autonomous region]" — "Bașcanului". Moreover, the Russian names of the cities of Moldova often sound in Romanian: Chișinău, Bălți, Orhei (compare: Kishinev, Balti, Orhei). Local residents in their oral speech, recorded in transcripts of synchronicities (short "video quotes" of newsmakers), can mix parts of the Romanian and Russian sayings: "Slava Domnului [Thanks God], there are medications, I am getting the necessary tratament [treatment] ..." (Vesti-Moldova, October 15, 18:15) examples of so-called Moldovenisms [Ionova, 2007: 79].

The speeches on the air of TV-channel under study are characterized by the intersection of reduced conversational and formal business styles (jargon in Russian): "Mikhail Khodorkovsky's henchmen advise not to spend a lot on an accompanying person. If anything - download the rights" (January 14, 20:00) - probably in this case we can talk about a failed method of pun; while in the subtitles, the quote itself is not quoted. Another example is contained in the story about a wild animal that came out of the forest to people: "In search of food, a seemingly exhausted polar bear prowls around the village" (April 18, 19:00) - the used word form of the verb "prowl" from a conversation vocabulary does not follow the news release format. TV-host pronounces words with diminutive-affectionate suffixes quite often: "brand-new cars" (January 15, 17:45); humorous phrases: "Further news from the category" you can't think of it on purpose "' (January 19, 23:30); symbol “@” "doggy” (January 17, 20:00).

A special specificity is also manifested in usage of means of expression: aphorisms and sayings were revealed in the January programs, which is not typical for the April, July and October release of programs. This tendency is especially vividly manifested in the spiegel (announcement at the beginning of the issue): "To whom is a hindrance, and to whom an opportunity to replenish their wallet: how savvy citizens came up with an idea to earn extra money on the snow" (Russian idiom) (Vesti-Moldova, January 14, 17:45); "Once on Epiphany evening, the girls wondered... why does winter in Moldova turn into a natural disaster every time?” (from Russian poem 'Svetlana', written by V.Zhukovsky), "If you're drowning, you're on your own: who should clean the capital's sidewalks and courtyards from snow?" (Russian idiom), "I look at you like in the mirror: Why do electoral competitors nominate namesakes in single-mandate constituencies?” (from popular Russian song 'The Mirror', written by Yu. Antonov) ("Vesti Nedeli-Moldova”, January 19). At the same time, the diversity of any established expressions in the texts of the BZ ("without sound", brief information read out by the host and accompanied by a video sequence) or plots of the January programs "Vesti-Moldova", "Vesti nedeli-Moldova" were not observed.

One more common meaning of expressiveness of speech should be noted in the studied programs - as a rule, epithets are unusual for the language of television information genres. Nevertheless, the results of the study have shown similar examples in the author's program "Vesti nedeli-Moldova": "And now nothing remains of the mysterious word 
"rock" carved in Greek letters on the wall of the gloomy tower of the cathedral. Nothing but a fragile memory "(April 20) - a rather lyrical beginning, breaking out of the usual rhythm of the text for news, seems to be quite justified, because it was spoken about a relic of world significance - Notre Dame Cathedral, about which many residents of Moldova (and other countries) know from eponymous novel by V. Hugo.

Another example of an issue is related to a story about a chinchilla farm in Moldova: "This cutest creature is gaining popularity among breeders", where the use of the epithet "cutest" is quite justified, although in the context of the main business news set out in the official language, the word sounds somewhat strange.

In the course of the study, changes in language techniques and features of the spiegel's offscreen text were observed depending on the personal factor - the change of the hosts of the final weekly program "Vesti Nedeli-Moldova" (O. Kairiak / G. Popova): a departure from a certain "flavor" of style towards its official "classics".

In the oral speech of the correspondents of the RTR Moldova TV channel, the specificity of the Russian language in Moldova is actively traced. As a result of the analysis of on-air transcripts, the following pronunciation trends were identified:

1) [i] instead of the orthoepically correct [y] after the preposition " $v$ " in one phonetic word: "[v'i]ssledovanii" instead of "[vy]sledovanii" (in English — 'in research'); "[v'i]zgotovlenii" instead of "[vy]zgotovlenii" (in English - 'in making'); "[m'ist'ir]" instead of the orthoepically correct "[m'ister]": "Miss and mister were chosen";

2) [a] instead of the orthoepically correct [e] in words with an unaccented vowel: "the traffic controller provokes traffic-jams during rush hours (in Russian 'hours' is 'chasy')" - [chasy] instead of [chesy]; "...master classes on painting Easter eggs (in Russian 'eggs' is 'iaits')" - [iaits] instead of [eits];

3) a falling out vowel in words instead of orthoepically correct avoiding it: "...then we take it to the building and give warm drinks, gradually (in Russian 'gradually' is 'postepenno') moving to hot ones" - [pas't'iep'en"] instead of [p"s't 'iep'en"].

Such deviations in the pronunciation of the sounds of Russian language in the country are explained by the influence of the softness of the vowels and consonants of Romanian language, as well as the transition in everyday speech from one language to another, which have different phonetic characteristics.

In the course of studying the media speech on television, several groups of stylistic and orthoepic deviations were identified:

1. inconsistency of parts of the speech - cannot give examples in English, because of Russian grammatical specifics (declension of case forms);

2. lexical inconsistency: "The Ministry of Education should announce the number of budget places for each university in the near future, last year there were a little less than a thousand of them" (July 16, 16:45); "Mihai Eminescu is a literary genius who managed to win hearts and artistic tastes around the world" (January 15, 20:00); "The stumbling block was the agenda in the Chisinau Municipal Council" (January 16, 17:45);

3. vagueness of the wording of a complex proposal - cannot give examples in English, because of Russian grammatical specifics; 
4. tautology: "About 15 employees were employed on the square..." (January 15, $17: 45)$;

5. violation of the style of the text: "His professor at Stanford is scandalized with what is happening..." (January 15, 17:45);

6. illogical narration: "But only after a short advertisement, it won't be long - don't switch" (January 19, 20:00);

7. incorrect declension of numbers - cannot give examples in English, because of Russian grammatical specifics (declension of case forms);

8. incorrect staging of the accent - cannot give examples in English, because of Russian grammatical specifics.

The main conclusions. Summing up the conversation about the stylistics of the journalistic genre of the article, we note that, in general, the data obtained from the study allow us to conclude the peculiarities of usage of Russian language in the states of the post-Soviet space. On the example of the information broadcasting of Russian-language TV-channel RTR Moldova, we can speak of a certain originality not only about broadcast media speech, but also about oral speech of local residents of the Republic of Moldova: bilingualism (the use of Moldovenisms in Russian speech) is widespread in the state, leading to various errors in Russian speech. It should be noted that this is not an exclusively linguistic phenomenon, it also depends on the socio-cultural aspect. The mixing of Russian and Romanian languages, demonstrated by examples, testifies not only to a certain linguistic "slovenliness", but also to the low level of education of the population. However, we should not deny the fact that such a manifestation of bilingualism is part of the expression. In the speech of television correspondents and presenters, the confusion of languages is not recorded. At the same time, the names of Moldovan cities in the studied programs sound without translation, which is also a manifestation of bilingualism.

Despite the real demand by the Moldovan audience of broadcast programs in Russian, the government of this state strongly supports the process of imposing content in Romanian on the viewer - every year the volume of Russian-language broadcasts is being cut more and more, which is confirmed by the facts from the history of RTR Moldova's functioning (introduction of fines, termination of broadcasting) and the current situation (since September 2019 newscasts in Romanian have been introduced into the on-air layout of the completely Russian-language TV-channel, their quantitative prevailed over news programs in Russian). That is why the analysis of the media speech of October issues turned out to be the least revealing.

\section{References}

Dolgova U., Peripechina G., (Eds). (2019). Television journalism. Moscow, Aspekt Press. (In Russian)

Ionova I., (2007). Functions of moldovenisms: bilingualism as a source of speech play. Rusin. International historical magazine, 3 (9), 79-88. (In Russian)

Kuznetsov G., Tsvik V., Yurovsky A., (2005). Television journalism. Moscow, MSU Publ.; Nauka Publ. (In Russian)

Kutsulab V., Rodionova A., (2018). Specifics of Moldavian bilinguism in colloquial speech. Russisms in Romanian language. Vestnik of MSLU. Humanitarian sciences, 1 (789), 77-81. (In Russian)

Mlechko T. (1997). Why did 'tysyatsky' become 'nanash' and who is guilty that I'm 'fina'? Vne Rossii. Sbornik nauchnykh statei o russkikh i russkoi kul'ture Moldovy (pp. 125-137). Kishinev. (In Russian)

Shtudiner M., (2017). The dictionary of difficulties of Russian language for media-workers. Accent, pronunciation, grammatical forms. Moscow, Slovari XXI veka Publ. (In Russian) 
Valgina N., Rozental D., Fomina M., (2002). Modern Russian Language. Moscow, Logos Publ.

Broadcast of Rossiya 1 TV-channel resumed. TASS. 15.01.2014. Retrieved from https://tass.ru/mezhdunarodnaya-panorama/888989 (In Russian).

Moldovan Parliament Speaker Passes Law Against Russian Propaganda. RadioFreeEurope. RadioLiberty. 11.01.2018. Retrieved from https://www.rferl.org/a/moldova-parliament-speaker-approves-russiamedia-law/28966975.html.

RTR-Moldova fined for the broadcast of the victory parade in Moscow. Deutsche Welle. 01.08.2018. Retrieved from https://www.dw.com/ru/rtr-moldova-назначен-штраф-за-трансляцию-парада-победы-измосквы/a-44909546 (In Russian)

RTR Moldova and other TV-channels remain out of reach. Moldovanews. 14.07.2014. Retrieved from http:// moldovanews.md/14012014/obshhestvo/1761.html (In Russian).

The centre of independent journalism. Retrieved from http://media-azi.md/ru.

Three key points in the national information space in 2018. Media Azi. 21.12.2019. Retrieved from http://media-azi.md/ru/stiri/три-ключевых-момента-в-отечественном-информационном-пространствев-2018-году (In Russian).

Population and housing census in the Republic of Moldova, 12-25 May, 2014. Natsional'noe biuro statistiki Respubliki Moldova.

Profi: Behind the scenes RTR Moldova. Aquarelle. 28.10.2013. Retrieved from https://www.aquarelle.md/ profi-za-kadrom-rtr-moldova-69904 (In Russian)

Received: August 1, 2020

Accepted: November 4, 2020

Authors' information:

Olga V. Tikhonova - Dr. Sci. in Philology, Associate Professor; tihonovao@list.ru

Anastasia A. Slobodyanyuk _ Master Student; staserl757@mail.ru

\section{Русская медиаречь в эфире телеканала «RTR Moldova»}

\section{О.В. Тихонова, А.А. Слободянюк}

Московский государственный университет имени М.В. Ломоносова, Российская Федерация, 119991, Москва, Ленинские горы, 1

Для цитирования: Tikhonova, O. V., Slobodyanyuk, A. A. (2021). Russian media speech on RTR Moldova broadcasting. Медиалингвистика, 8 (1), 83-89. https://doi.org/10.21638/spbu22.2021.107

Представлены результаты исследования особенностей русской медиречи в Республике Молдова на примере информационного эфира телеканала «RTR Moldova». Изучены фактическое положение русского языка на территории страны в рамках текущей политики государства, ситуация русскоязычного вещания в стране, исследован и систематизирован теоретический материал об особенностях русского языка в Республике Молдова, сделан обзор истории создания и особенностей функционирования русскоязычного телеканала «RTR Moldova» в условиях действующего законодательства. В исследовании применялись методы количественного и сопоставительного анализа, индукции, синтеза теоретических и практических знаний. В эмпирическую базу вошли видеоматериалы 41 выпуска программ «Вести-Moldova» и «Вести недели-Moldova». Общий хронологический период предпринятого исследования составил эфирный 2019 г. благодаря использованию «сезонной» выборки (по неделе зимнего, весеннего, летнего и осеннего времен года), что способствовало более объективному выявлению динамики медиаречи ведущих и корреспондентов телеканала «RTR Moldova». Классифицированы ошибки, относящиеся к грамматике, орфоэпии, стилистике закадрового текста, логике изложения оперативной информации, изучены особенности использо- 
вания средств художественной выразительности. Кроме того, обозначены тенденции билингвизма в устной речи жителей Республики Молдова, что отражается в телевизионном эфире. При этом подчеркивается, что эфирные программы на русском языке востребованы аудиторией, однако на государственном уровне всячески поддерживается процесс навязывания зрителю контента на румынском языке. В связи с этим объем русскоязычных передач с каждым годом сокращается.

Ключевые слова: билингвизм, языковая интерференция, медиаречь, телевидение Молдовы.

Статья поступила в редакцию 1 августа 2020 г; рекомендована в печать 4 ноября 2020 г.

Контактная информация:

Тихонова Ольга Владимировна - канд. филол. наук, доц.; tihonovao@list.ru Слободянюк Анастасия Александровна — магистрант; staserl757@mail.ru 